\title{
$\triangle$ DIsOLAIMFR.
}

To the Ifditore of "ThE Jovkral or Marrax Bctawce"

Grivtumant,-Bome month since, in common with other medical superin. tendents of the Lancashire and Yorkshire Asylums, I received from the Editor of "The New York Medico-Legal Journal" a ciroular letter on Restraint, as practised in American and British asylums. This ciroular embraced the published communications of a large body of American alieniste the expression of whose views on the subject had been invited; and I regarded this rather unusual procedure as implying that British superintendents were invited to forward their own convictions (if they desired) to the Editor of "The Now York Journal."

This procedure did not recommend itself to $\mathrm{my}$ adoption, for, with respect to the general question of exposing to odium the opinions of those who differ from us upon any principle of treatment, it appeared to me not only a retro. grade step in medioo-othios, but an inquisitorial infringement of the liberty of the subjeot and individual judgment, entirely opposed to the best tendencies of the age. I desire to make no further comment here on the very ill-advised circular, beyond indicating that as a purely business arrangement each reoipient had endorsed the fly-leaf ere forwarding it to his brother superintendentobviously to aroid its being returned to him a second time. I, in common with others, did this; but I am now told that this might be regarded as an endorsement of the general tone of the circular itself, and, moreover, what is more to the point, might be regarded as implying our concurrence with a most ungenerous and unjustifiable attaok made upon two of our most respected English alienists, whose opinions I, for one, hold in the highest esteem, and whose names are household names in English lunaoy. This imputation, Sirs, I desire most emphatically to repudiate, and, moreover, would desire not only to express my hearty sympathy with those who have the courage of their opinions despite all odds; but also, whilst deprecating the publication of the letter referred to, wonld wish to express my very sincere personal concern that any such endorsement of the circular letter by myself should have been 80 interpreted. From what I have already heard from other superintendente I judge that no such invidious meaning was for one moment entertained.

$$
\text { I am, Gentlomen, }
$$

$$
\text { Yours very faithfully, }
$$

West Biding Asylum, Wakefield,

\section{W. BEVAN ITWrs.}

\section{Obituary.}

\section{WILLIAM WOOD, M.D., F.R.O.P.}

Dr. Wood's health had been failing for some time, so that surprise was not felt, considering his age (76), when it was announced that an attack of congestion of the lungs had ended fatally on the 27th of August. After his medical education at University College, he passed some time in the Paris Schools of Medicine, and in 1848 took his M.D. degree at the St. Andrew's University. In 1864 he was elected a Fellow of the Royal College of Physicians, London. We have heard him speak of Dr. Flliotson with great respect, and as having assisted him in his experiments in what was then known as mesmerism at Cniversity College. In 1845 he was elected to the post of resident modical 
officer at Bethlem Hospital, and held the office until 1852. The governors had succeeded in their attempt to exempt the hospital from the visitation of the Lunacy Commissioners, required by the Lunacy Acts; the organization of the staff, medical and non-medical, resident and non-resident, was most unfortunate, and worked disastrously. The rules crippled the action of the resident surgeon, and vested too large an authority in the visiting surgeon and physicians, who, it must be admitted, utterly failed in their duty. Hence it was impossible that Bethlem could be managed satisfactorily, and an official inquiry led to its being placed on the same footing as other registered hospitals, and under the inspection of the Commissioners. The result was that Dr. Wood resigned. From that time he proved his energy and force of character by his successful career as an alienist. He was in the first instance a partner in a private asylum at Kensington. He became before long sole proprietor, and resided in Harley Street. He was appointed visiting physician to St. Luke's Hospital in 1861. It is quite recently that he resigned the appointment and became consulting physician.

The Priory, Roehsmpton, was purchased by him in 1870. To it two years afterwards he transferred his patients from Kensington House. He conducted his asylum with the energy and kindness which were to be expected from him. He added largely to the original buildings, and "The Priory" justly stands in the first rank of licensed houses.

Dr. Wood was at one time President of this Association, and took an active part in its proceedings for many years.

He strongly opposed Mr. Dilwyn's Bill for the abolition of private asylums, and with equal vigour certain clanses in the Lunaoy Bill of 1889 and 1890 . He could never reconcile with his views the interference of the magistrate in the admission of patients into asylums, and he applauded the course pursued by the Earl of Shaftesbury when Lord Selbourne introduced the Bill. He spoke with contempt of the vexatious and petty clauses by which the Bill was disfigured. As is well known, those which bore hardly on licensed houses were greatly modified by the exertions which he, in common with other asylum proprietors, especially Dr. Hares Newington, made.

Dr. Wood was not a great writer, but contributed several articles to "The Journal of Mental Science," "The British and Foreign Medico-Chirurgical Review," and "The Journal of Psychological Medicine," as also two brochures on "Insanity and the Lunacy Laws" and "The Plea of Insanity."

The funeral of Dr. Wood, at Putney, was attended by a large number of mourners desirous to pay the last tribute of respect and affection to his memory.

\section{EXAMINATION FOR CERTIFICATE OF PROFICIFNGY IN} NURSING.

The next examination for this certificate will be held on the first Monday in November. All inquiries in connection with this examination should be addressed to the Registrar,

$$
\text { Dr. Sprerce, }
$$

Burntwood Asylum, Lichfield, And not as heretofore to the General Secretary.

Winner of the Bronze Medal and Prize of 10 Guineas,

G. M. Robertson, M.B., C.M., Senior Assistant Physician, Morningside Asylum, Edinburgh. 